\title{
Contextualising the Arabic Nomenclature of Coronelli's Celestial Globe at the Biblioteca Federiciana in Fano
}

\author{
Celeste Gianni \\ SOAS, University of London \\ Al-Furqan Islamic Heritage Foundation \\ celeste.gianni@al-fuqan.com \\ George Saliba \\ Director Farouk Jabre Center for Arabic \& Islamic Science and Philosophy \\ American University of Beirut (AUB) \\ P.O. Box II-O236, Riad El Solh IIO7 2020, Beirut, Lebanon \\ gsaliba@aub.edu.lb \\ Michele Tagliabracci \\ Biblioteca Federiciana, Fano, Italy \\ michele.tagliabracci@comune.fano.pu.it
}

\begin{abstract}
At the end of the $I 7^{\text {th }}$ century, different editions of the terrestrial and celestial globes by the geographer and cosmographer Vincenzo Coronelli (I650-I7 I 8) were circulating all around Europe. After the production of two large globes $(384 \mathrm{~cm}$ in diameter) for Louis XIV ( I68 I-I683), Coronelli's pair of terrestrial and celestial globes had acquired enough prestige to hit the market as geographical and astronomical instruments, but also as grand decorative and collectible objects. The construction of a globe was a complicated operation characterised by different phases of production: Coronelli was firstly producing the gores of the globes that had to be engraved and printed for "mass" distribution. However, the printed material was only the skeleton of each globe. Framed sections were left empty in order to add customised dedicatory inscriptions as well as further details on the donation or purchase of the object; also, geographical and astronomical notations were written by hand at a later stage, the colouring of the globes was optional and came at a higher price, and the globes were then installed in different types of pedestals. Coronelli's globes

Gianni, Celeste; Saliba, George; Tagliabracci, Michele (2018-2019). «Contextualising the Arabic Nomenclature of Coronelli's Celestial Globe at the Biblioteca Federiciana in Fano». Suhayl I6-I 7, pp. 323-343. ISSN: I5769372. DOI: IO.I344/SUHAYL20I9.I6-I7.7.
\end{abstract}


were different in size and installation, but also in design and content. Consequently, each globe should be considered a unique object that deserves to be described on its own as well as understood in the context it was meant to be placed.

In particular, Coronelli's celestial globes have been the object of few studies and the retracing of their history of production has often been difficult to define with certainty. For example, the first major studies on Coronelli's I Io cm $\left(3^{1 / 2}\right.$ feet) celestial globes suggested that he produced 6 different engraved plates between $\mathrm{I} 688$ and $\mathrm{I} 707,{ }^{\mathrm{I}}$ but recently it has been confirmed that only 3 different engraved plates were used, and that the differences between the globes are due to the customised manuscript additions. ${ }^{2}$

One of the handwritten elements that characterises Coronelli's celestial globes and makes each of them unique is the Arabic nomenclature of stars and constellations. Names of stars and constellations were also given in Latin, Italian, French and Greek. Arabic nomenclature appears in several editions of Coronelli's celestial globe, including on the great globe produced for Louis XIV. It is not the first instance of Arabic nomenclature used in European globes, as already in I630, the Dutch cartographer Willem Janszoon Blaeu (I57I-I638) used Arabic script for names of the constellations, followed by Jacob Aertsz Colom (I600-I674) in I635. For Louis XIV's globe, Coronelli probably relied on a collaborator that was an Arabic speaker (or at least mastered Arabic calligraphy) and that used as source for Arabic astronomical nomenclature the Book on the Constellations by Abū alHusayn al-Ṣūfī (903-986), already used by Colom as a source for the Arabic nomenclature of his globe. ${ }^{3}$ However, for Coronelli's later globes the calligrapher and the sources vary in accordance to the model and time of production.

Keeping with the tradition that had already been established during the seventeenth century by Willem Janszoon Blaeu (I57I-I638) and Jacob Aertsz Colom (I600-I674) of adding, in Arabic script, the names of the constellations, stars, and in some cases even lunar mansions (as in the case of Colom), Coronelli was very

I. M. L. Bonelli, "I globi di Vincenzo Coronelli”, in Istituto e Museo di Storia della Scienza . Biblioteca III. Catalogo dei globi antichi conservati in Italia, Fasc. 2 (Firenze: Olschki, I960).

2. M. Milanesi, "Coronelli's large celestial printed globes: a complicated history", Der Globusfreund, 47/48 (Wien: Coronelli-Weltbund der Globusfraunde, I999/2000): I43- I60.

3. P. Kunitzsch, "The Arabic nomenclature of Coronelli's great celestial globe: its sources and a comparison to the Arabic inscriptions on other types of his globes", Zeitschrift für Geschichte der Arabisch-Islamischen Wissenschaften, I9 (Frankfurt am Main: Institut fur Geschichte der ArabischIslamischen Wissenschaften an der Johann Wolfgang Goethe-Universitat, 20 I O-20 I I): 235-242. 
keen in maintaining the Arabic nomenclature of stars and constellations at least on some of his own globes. He even seems to have supplemented his knowledge of the previous globes by undertaking additional research of his own in other sources for such nomenclature. As Kunitzsch had already conjectured, ${ }^{4}$ for Coronelli the use of Arabic, in original script, which had already been applied by Blaeu and Colom, was one aspect of keeping up with the high scientific standards of the time. For at the height of the Renaissance, the three languages, Latin and Greek together with Arabic, were then perceived as the "three historically important languages".

Of all the globes produced by Coronelli, the awe-inspiring $384 \mathrm{~cm}$ (in diameter) pair of globes made for the great Sun King, Louis XIV, has received the lion's share of studies currently known to us..$^{5}$ In addition to that, the various articles of Paul Kunitzsch devoted to the nomenclatures on the smaller-size globes, as well as others with Arabic nomenclature, have gone a long way in explaining the circumstances of the Arabic constellation captions on such globes as well as the etymologies of the Arabic terms and their sources whenever possible. And yet there are still several inconsistencies and problems with these Arabic nomenclatures on the various globes produced by Coronelli, some of which will be detailed in the following.

To start with, and for some unexplainable reason, in Kunitzsch's early article on Coronelli's celestial globes he had characterized some of those globes that carried Arabic captions as "trilingual", ${ }^{6}$ when in fact the great majority of them were quadrilingual, as is the case with the great Louis XIV globe, and even quintilingual as in the case of the Biblioteca Federiciana in Fano celestial globe under study, or even the very same globes Kunitzsch and Embleton studied from the Austrian National Li-

4. P. Kunitzsch and C. Embleton, "The Trilingual Inscriptions on some Celestial Globes of V. Coronelli”, Der Globusfreund, 40/4 I (Wien: Coronelli-Weltbund der Globusfraunde, November I992 for I992/I993), 67-76.

5. See, inter alia, the works of M. Bonelli, M. Milanese, and P. Kunitzsch already cited above in addition to Kunitzsch, "The Arabic nomenclature on Coronelli's I Io cm celestial globes", in Zeitschrift für Geschichte der Arabisch-Islamischen Wissenschaften, 9 (Frankfurt am Main: Institut fur Geschichte der Arabisch-Islamischen Wissenschaften an der Johann Wolfgang GoetheUniversität, I 994) 9I-98, and Kunitzsch's edition of Louis XIV globe in “Coronelli's Great Celestial Globe made for Louis XIV: Nomenclature", originally published in Zeitschrift für Geschichte der Arabisch-Islamischen Wissenschaften, I4 (Frankfurt am Main: Institut fur Geschichte der Arabisch-Islamischen Wissenschaften an der Johann Wolfgang Goethe-Universitat, 200I), 39-55, reprinted in P. Kunitzsch, Stars and Numbers: Astronomy and Mathematics in the Medieval Arab and Western Worlds, Burlingon Vt, Ashgate/Variorum, 2004, study XxIV.

6. Kunitzsch and Embleton, op. cit. 
brary. ${ }^{7}$ In fact, the globes illustrated in the 1992 study, like the others we will refer to from the Federiciana library, all exhibit quintilingual nomenclatures. In the illustrations used by Kunitzsch and Embelton for their article, they both demonstrate quintilingual nomenclatures. For example, the illustration they used for the Monoceros constellation, the nomenclature clearly reads as follows: "Licorno"/"Alicorno" (two Italian variant forms), "La Licorne" (French), "Monoceros" (Latin),

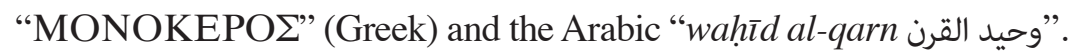

The Federiciana globe is still distinguished further by the fact that it carries, in addition to the five languages in the nomenclature, elaborate citations from earlier Latin sources about the legends and myths surrounding those constellations. Take the constellation of Cygnus on the Federiciana globe, for example, (Fig. I), where we find the following caption inserted by Coronelli: "CIGNO, LE CYGNE, CYGNUS, Alor, Avis, Milunuis (sic), Gallina, Vultur cadens, Myrtilus, Ledae Adulter,

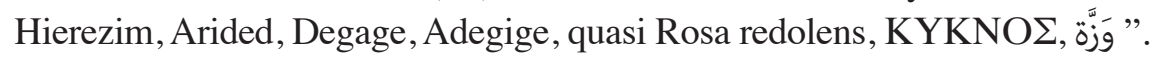
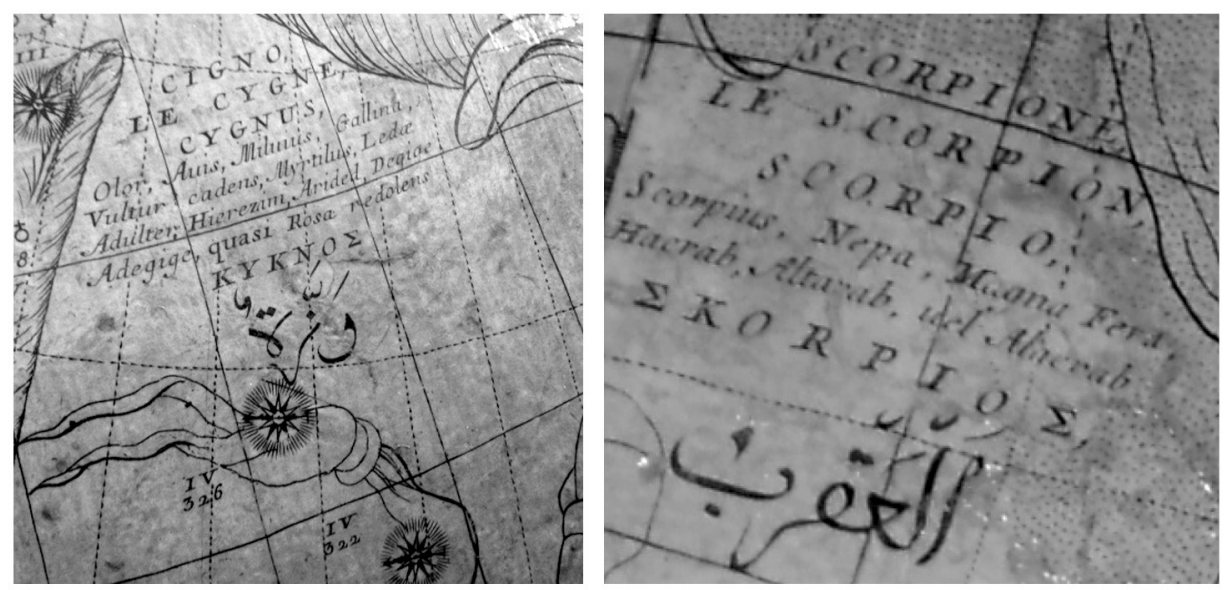

FiguRE I. Showing the nomenclature for the Cygnus and Scorpio constellations. ${ }^{8}$

7. See for example the two illustrations published in Kunitzsch and Embleton, op. cit., Fig. I I, I2, for the constellation of Monoceros, and Fig. I3 and I4 for the constellation of Piscis notius, taken from globes of the Austrian National Library GL 30, and GL 22 and GL3 I from the same library, respectively.

8. In the legend to this constellation, the long citation of the Latin variants is taken, almost verbatim, from the I679 comments of Michael FAYUs, on the Astronomicon of Manillius, Astronomicon Interpretatione et Notis ac Figuris Illustravit, Paris: Frédéric Léonard, I679, 45, to which the additional references to the variants in the Arabic names are taken, again almost verbatim, from Coronelli's own Epitome Cosmographica, Venice: Andrea Poletti, I693, 62. 
Or the caption for the constellation of Scorpio where he has: "SCORPIONE, LE SCORPION, SCORPIO, Scorpius, Nepa, Magna Fera, Hacrab, Altarab, vel Alacrab, $\mathrm{KORPIO} \Sigma$ (sic instead of $\Sigma$ KOPMIO $\Sigma$ ), and finally العقرب".

In both instances, we find the heavy reliance on Manilius's Astronomicon for the Latin variants, and the Epitome for the other languages including the Arabic variants. And here again, we find further confirmation of the quintilingual production of the Federiciana globe in contrast to the quadrilingual captions on the grand globe of the Sun King Louis XIV.

Other constellation captions present particular difficulties that have not been adequately resolved so far. In his foundational article on the Arabic nomenclature on Coronelli's smaller globes, already noted above (n. 5), Paul Kunitzsch raised two very important philological issues related to the peculiar usage of Arabic terms on the globes he was studying. The first issue concerns the constellation of Corona Borealis, indicated in Arabic as Tāj al-Gharbī (تاج الغربي) on the small globes produced by Coronelli, including the Federiciana's globe, as can be seen in Figure 2 below:
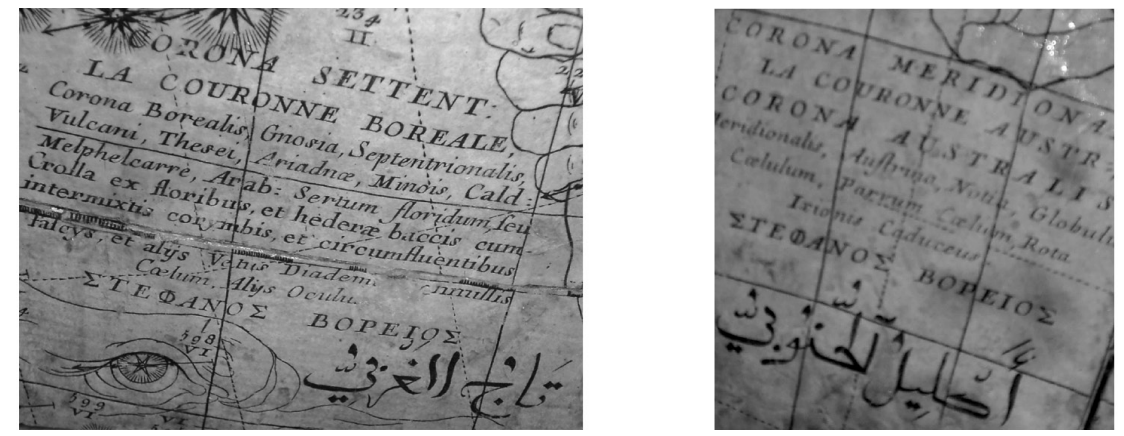

FIgURE 2. The Arabic designation of Corona Borealis on the Federiciana globe as tāj (instead of al-tāj) al-gharbi تاج الغربي in contradistinction to the southern corona here named $i k l \bar{l} l$ (instead of $a l$-iklīl) al-janūbì, (sic) أَكليل الجنوبي the southern crown.

9. In the same manner as in the previous constellation, here too Coronelli drew on the commentary of Michael Fayus, on Manilius Astronomicon, op . cit., 35, to list all the Latin variants for Scorpio. In his Epitome of I693, he has for the Arabic names of Scorpio the following: "Nakrab (spelled Hacrab on the globe instead of just simply Acrab), Altarab, (as on the globe an obvious mistake resulting from a metathesis between the letters ' $t$ ' often confused with ' $c$ ' and the following letter ' $a$ ', which should have been read correctly as Alacrab as was rendered on the globe in the last variation), Alauab (an obvious misreading of the letter ' $c$ ' followed by ' $r$ ' here conjoined as one letter ' $u$ ' when the word is spelled correctly on the globe as Alacrab)". The Greek name in the Epitome has the correct spelling for $\Sigma \mathrm{KOP \Pi IO} \Sigma$, unlike the confused Greco-Latin spelling on the globe. 
For the unsuspecting reader or viewer of the globe the Arabic term al-gharbi , would normally mean "the western". But since there is no such western crown, Kunitzsch correctly suggested in the same article, note I4, that this term should not be read as Arabic, rather it should be understood as taken over from Syriac, ${ }^{\circ}$ where the term garbya , or garbya $\bar{y} \bar{a}$, could mean north, or northerly thus correctly identifying the constellation as northern, in contradistinction to the southern crown, known in Arabic as al-Iklīl al-Janūbì. In fact, the Syriac text of Bar Hebraeus's Ascension of the Spirit (Loor Low = Sūloqā hawnonoyā) clearly

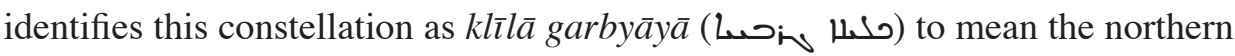
crown i.e. Corona Borealis. ${ }^{I I}$ The same expression is also used by the much earlier Syriac writer Severus Sebokht (d.c. 666) in a treatise on the constellations now preserved at BNF Syr. Ms 346, fol. 9Ir.

The obvious use of Syriac sources to identify this constellation must mean that once he was back in Venice, around I684, or so, Coronelli sought the help of a native speaker from the East Mediterranean who was obviously familiar with both Syriac and spoken colloquial Arabic, and thus could have consulted such major astronomical Syriac works. This would explain why this assistant would almost transliterate Syriac garby $\bar{a} y \bar{a}$ into Arabic $a l$-gharbī, and unwittingly retain the Syriac meaning of the term "northerly" rather than what the Arabic transliteration would indicate as westerly.

This becomes all the more puzzling since in the production of the grand celestial globe for Louis XIV Coronelli and/or his assistant had correctly identified this constellation with the traditional Arabic name al-Iklīl al-Shamālī (الاكليل الشمالي) as he also did for the southern one as al-Iklīl al-Janūbi (الاكليل الجنوبي)."22

In the same vein, and to compound the linguistic problems Coronelli must have faced after returning to Venice, we also find on the Federiciana globe, as in Fig. 3 below, the name of the constellation Piscis Austrinus given as what looks like (حوت نصف النهايّي), as read by Kunitzsch, ${ }^{13}$ and interpreted by him as a mistake for

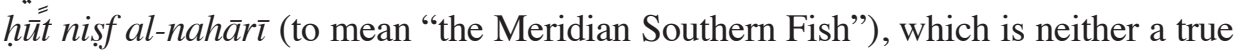
constellation nor is it mentioned by anyone before or since in that form. ${ }^{14}$

IO. Kunitzsch, "The Arabic nomenclature", op. cit., note I4, 94-95.

i i. See, Bar Hebraeus, François Nau, Livre de l'ascension de l'esprit, Paris: E. Bouillon, I 899, I I I.

I 2. See, Kunitzsch, "Great Celestial Globe", op. cit., 44, and 49 respectively.

I3. Ibid., 50

I4. Ibid. 


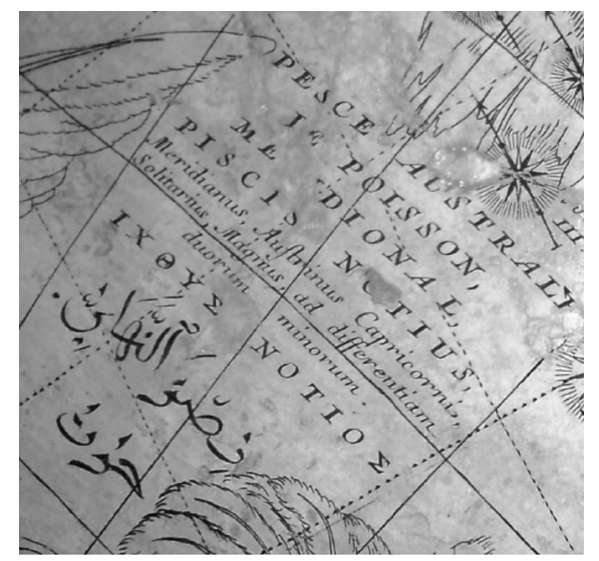

FIGURE 3. The nomenclature for constellation Piscis Notius, with the enigmatic reading signaled by Kunitzsch more than once.

When Kunitzsch first encountered this puzzle on the Austrian National Library ${ }^{15}$ globe GL 3 I he said at the time that "the characters used in the same word on LibGL22 and GL 30-3 I are so distorted that no Arabic letter can be clearly identified". This is in fact the same constellation that Coronelli had identified correctly on the grand globe of Louis XIV, years before he produced the Federiciana globe, as al-hyut $a l$-janūb $\bar{\imath}$ (the Southern Fish). This must mean that the assistant who helped Coronelli identify this constellation correctly as al-ḥut al-janūb $\bar{\imath}$ when he was in Paris working on the grand globe was no longer available to him when he returned to Venice and thus had to engage another assistant who was not familiar with the nomenclature that was used on the grand globe. The puzzle becomes slightly easier to solve if we attempt another reading of the Arabic nomenclature, which was apparently produced on most of the I IO $\mathrm{cm}$ globes, including the Federiciana globe. What seems to have engendered the puzzle was the misreading of the first Arabic word in the phrase of the nomenclature as "nisff", with the first letter assumed to be a "nūn". But taking into consideration the fact that the Arabic hand-written letter " $n \bar{u} n$ " can be easily confused with a careless rendering of the letter " $f \bar{a}$ ", , both having to have a dot above, we can then realize that the assistant who penned the new name on these smaller globes was not translating the name of Piscis into Arabic, but rather was attempting to transliterate it starting with the name Piscis. Since Arabic

I5. Kunitzsch, “Trilingual”, op. cit., 76. 
does not have the letter " $p$ " this letter was usually rendered with the Arabic letter " $f$ '. Thus, the word Piscis was rendered as fișiz (فصيز) with the missing dots under the $y \bar{a}$ ', which is not unusual, and carelessly rendering final letter "zayn" which could be confused with a final form of the letter " $f \bar{a}$ "'. The same assistant who transliterated the letter " $p$ " with a " $f \vec{a}$ " "was in all likelihood the very same person who also transliterated - rather than translated - the name of the constellation Ophioucus can easily see the similarity in the rendering of the same phoneme " $f / p h$ " with the same Arabic letter " $f \vec{a}$ " " transliteration of Piscis reading of the first word as a transliteration rather than a translation.

The second term on most of the I IO $\mathrm{cm}$ globes - including the Federiciana nomenclature for this constellation - was read correctly by Kunitzsch as (النهائيّ) $=$ the last $) \cdot{ }^{17}$ But then he thought that it was a mistake for al-naharri , meridiónal, which is difficult to defend. Our suggestion is that it should indeed be read as al$n i h \bar{a} ' \bar{l}=$ meaning the final or the last, in agreement with the reference to the same constellation by Apianus, ${ }^{18}$ where he characterizes it as the last: "Piscis notius postremus est", and is in fact the very last constellation Apianus mentions in his list. It is also the last in Șūfī’s Șuwar al-kawākib al-thābita (Book of the Fixed Stars). So Coronelli's assistant probably meant to say "Piscis the last Fish", or something to that effect trying to reflect Apianus's characterization of it.

As was stated above, since this constellation was correctly identified, using the well documented traditional Arabic name of al-ḥut al-janūb $\bar{\imath}$, when Coronelli was producing the grand globe for Louis XIV, around the years I682-I683, then why was this information discarded and replaced around the year I693 with an awkward transliteration of the name Piscis, and a borrowed description from Apianus that was translated into Arabic as al-nih $\bar{a}^{\prime} \bar{l}$ ?

This and other such questions seem to be encountered when considering some of the features of Coronelli's smaller globes. Such questions seem to imply that there was a real loss of information during the decade or so that separated the making of the grand globe and the smaller globes such as the one at the Federiciana.

i6. Vincenzo Coronelli, Libro dei Globi, Venezia i693 (I700), Theatrum Orbis Terrarum, with an introduction by Helen Wallis, Amsterdam, I969, gore for the constellation here marked in Latin as "Serpentarius", and OФIOYXО $\Sigma$ in Greek.

I7. Kunitzsch, "Great Celestial Globe", op. cit., 50.

I8. ApIAnus, Astronomicum Caesarum, Ingolstadt: Peter Apianus, I 540, s.v. "Piscis Notius". 
Other features also include the kind of Arabic that Coronelli's assistants were using during these later years. We have already mentioned the use of the term garby $\bar{a} y \bar{a}$ derived from Syriac rather than Arabic to refer to the northern direction. Add to it the use of the term qibli (instead of janūb $\bar{\imath}$ ) to identify the southern direction, or the term 'adhrā (with alif maqșūra) for Virgo instead of the more classical al- 'adhra $\vec{a}$, or the term al-jawzah instead of the more classical al-jawz $\vec{a}$ ' for Gemini, and using such terms as al-jidi, for Capricorn instead of the more classical al-jady, or wazza, for the constellation of Cygnus (here misplaced instead of Lyra which was called awazza, in BNF Arabic ms 5036 copy fol. 52V or the printed text of Sūfī's work p. 67). All these features and many others clearly indicate that Coronelli's informant(s) who advised him in Venice was/were less educated and were apparently more familiar with colloquial Arabic terms of the Eastern Mediterranean in contrast to the assistant who advised him on the grand globe while in Paris and who was apparently much better educated in such matters.

Finally, there is the peculiarity of the name of the constellation Phoenix, which was called nädira on the Louis XIV's globe, and $a l$ - 'uqā $b$ on the Federiciana and most other I Iocm globes, a name that was applied to the constellation Aquila on the Louis XIV globe. Aquila on some of the gores of the Libro dei globi (as in the Federiciana) is identified as al-nasr, while it is called al-nasr al-wāqi on other gores and presumably globes derivative from them.

Some answers to these questions can be found by studying and understanding the context in which these globes were meant to be used and placed. If major attention has been given, for instance, to the great globe of Louis XIV and to the most renowned globes housed at the Museo Galileo in Florence, less attention has been granted to minor institutions and personalities that purchased the globes at the time. Yet, the documentation available for such realities could provide relevant proof of the constant interaction between different cultures towards the development of the sciences - astronomy in this case and the use of native informants by Coronelli from the Eastern Mediterranean that we just mentioned when he was back in Venice - as well as enlightening less known aspects and dynamics of this interaction.

One of these less known instances is the history of the I I $\mathrm{cm}\left(3^{1 / 2}\right.$ feet) celestial globe purchased by Domenico Federici ( $1633-\mathrm{I} 720$ ) ${ }^{19}$ for his personal library that he established in the oratory of the Congregation of Oratory of Saint Philip

I9. M. Tagliabracci, "L'avventurosa vita di Domenico Federici," Nuovi Studi Fanesi, 24/25 (Fano: Biblioteca Comunale Federiciana, 20 IO/20I I): 27-IO4. 
Neri housed in San Pietro in Valle in Fano (Marche, Italy). ${ }^{20}$ Together with I 2,000 volumes, the library housed scientific and astronomical instruments as well. The library was opened to the public in 1720 , at the death of Federici, who endowed it for the benefit of the town.

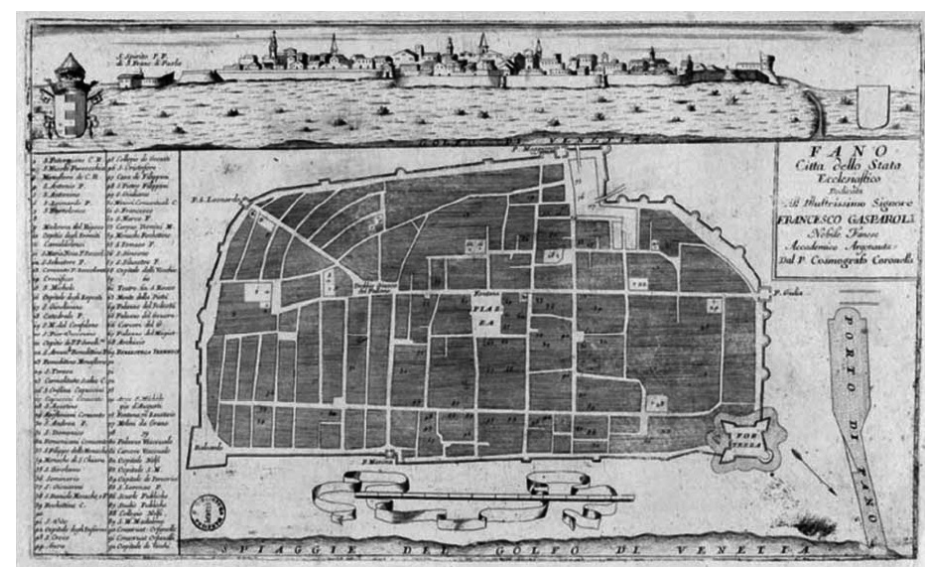

FIGURE 4. In addition to a pair of globes, Coronelli dedicated to Francesco Gasparoli, a noble from Fano, a map of the city of Fano in Stato Ecclesiastico ( I696) also published in Teatro delle Città ( I697).

Since I667, Federici was Residente cesareo - diplomat for Leopold I of Habsburg - in the Republic of Venice, and collected art works, books and antiquities on behalf of the Court of Vienna as well as for his private collection. He was in contact with Coronelli and purchased several of his books ${ }^{21}$ as well as the globes.

20. There are other two globes $(490 \mathrm{~mm})$ by Coronelli in the town of Fano in the Count Castracane degli Antelminelli's collection released either in I 696 or in I699. They do not have Arabic nomenclature. See: F. BonAsera, "Terrestrial and Celestial Globes by Vincenzo Coronelli, I688," Imago Mundi. A Review of Early Cartography, Io (Stockholm,- Leiden: E. J. Brill, I953): 79-80. Moreover, Coronelli dedicated two globes $(6 \mathrm{~cm})$ to the noble Francesco Gasparoli from Fano in I693 (the gores of these globes are included in Book x of the Atlante Veneto, table I53). See: F. Bonasera, Vincenzo Coronelli cosmografo della Serenissima (I650-I7 I8). Vita ed opera (Ancona: Comitato per le onoranze nelle Marche al padre Vincenzo Coronelli nel tricentenario dalla nascita, I950): 25; C. PongetTi, "Nella sfera del Coronelli. Il contributo cartografico alla congiuntura tra Venezia e le Marche," in R.M Borraccini, G. Borri (ed.), Virtute et labore: Studi offerti a Giuseppe Avarucci per i suoi settant'anni, (Spoleto: Fondazione centro italiano di studi sull'alto Medioevo, 2008), v. I: 429-464.

2 I. In the manuscript catalogue (I720 ca.) of the Biblioteca Federiciana, Coronelli's works are listed under "Vin" (i.e. Vincenzo Coronelli) the following titles: Cronologia Universale, 
He must have been an esteemed patron, because Coronelli dedicated to Federici a map made in I688 and included in the Corso geografico (published in I692), titled "Stato di Ragusi, Bocca del F. Narenta, Isole di Lesina e Curzola nella Dlamatia possedute dalla Serenissima Repubblica di Venetia dedic: all'Ill.mo Sig. Doemnico Federici, Abbate di Vaska, Consigliere di S. Maestá Cesarea", 22 and a book titled "Ritratti de' celebri personaggi" (Portraits of famous personalities) published in I697. The map and the volume Ritratti have two different portraits of Federici (one portraying the profile, one from the front). They were inserted in the volumes at a second stage, both to complete the map and to decorate the antiporta of the Corso geografico (part of the I3 volume Atlante Veneto).
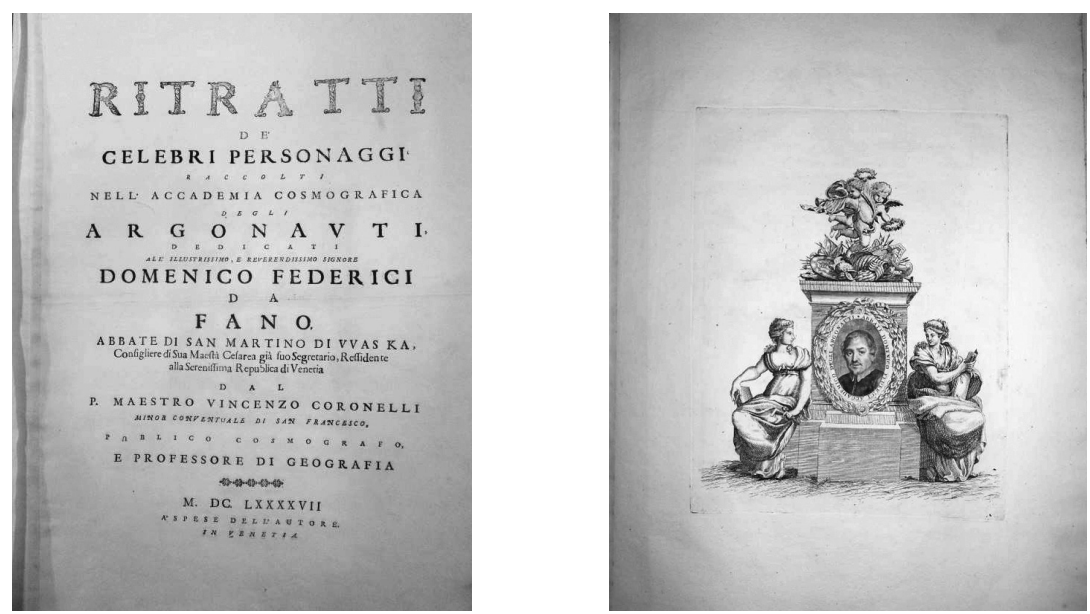

Figures 5-6. Title page of Ritratti de' celebri personaggi ( I697), dedicated to Domenico Federici. On the opposite page (the antiporta), the portrait of Domenico Federici.

\footnotetext{
Tavola Sinodica de Cardinali, Ritratti de Personaggi, Epitome Cosmografica, Corso Geografico Universale, Atlante Veneto, Isolario dell'Atlante Veneto. In the card catalogue of the pre-modern collection, under "Cor" (i.e. Coronelli), the following titles are listed: Cronologia Universale, Tavola Sinodica de Cardinali, Ritratti de Personaggi, Epitome Cosmografica, Corso Geografico Universale, Atlante Veneto, Isolario dell'Atlante Veneto and I viaggi del P. Coronelli.

22. The map appears in Coronelli's Corso geografico universale, o sia la terra divisa nelle sue parti, e subdistinta nè suoi gran regni. Esposta in tavole geografiche, ricorrette, et accresciute di tutte le nuove scoperte, ad uso dell'Accademia cosmografica degli Argonauti dal padre maestro Vincenzo Coronelli M. C. Cosmografo della serenissima Republica di Venetia (Venice: Vincenzo Maria Coronelli, I692). A copy of the publication is in the Biblioteca Federiciana (Shelf mark: 2 M VIII 002 I).
} 

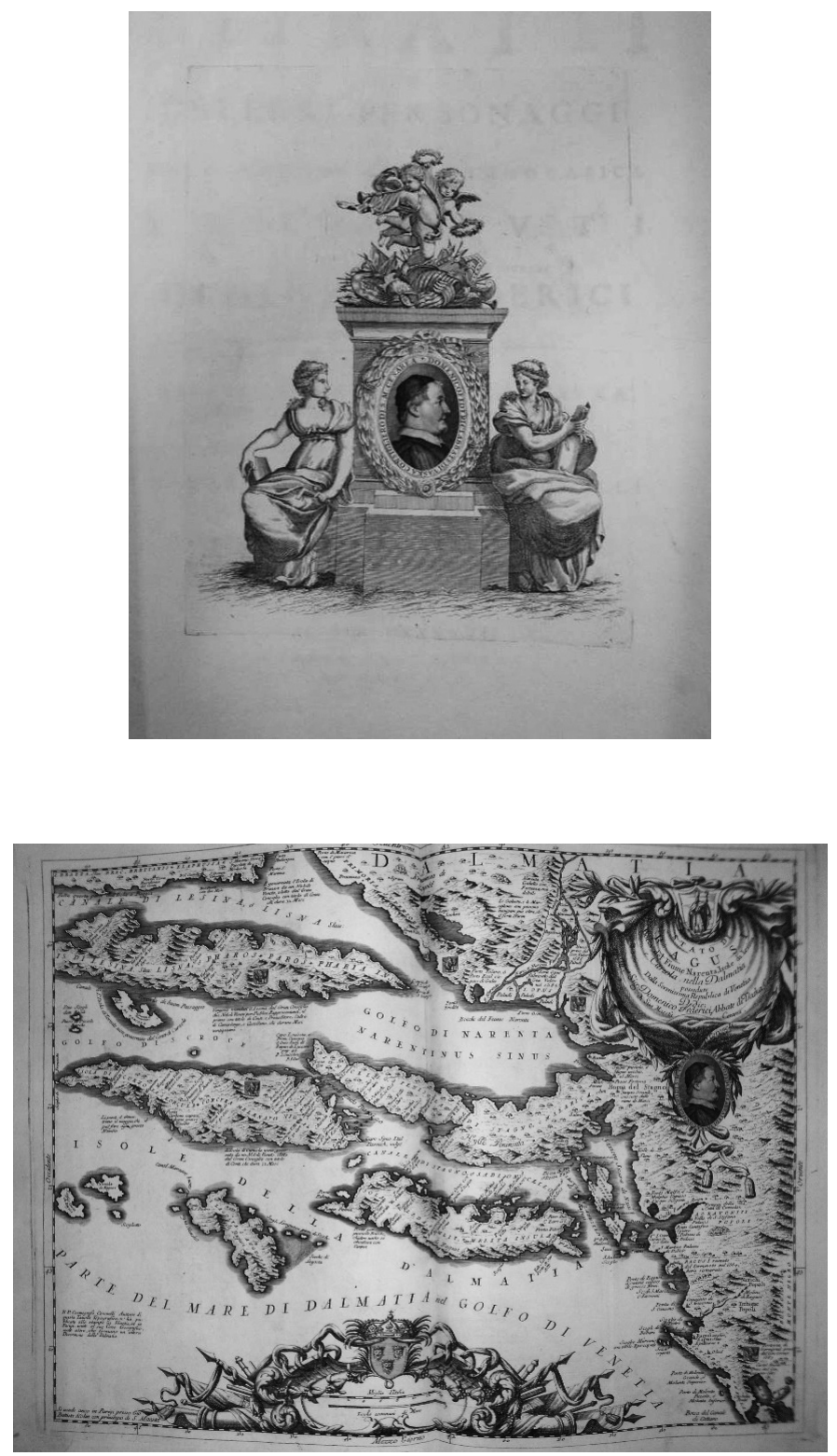

FIGURES. 7-8. Another portrait of Domenico Federici appears in the antiporta of the Corso geografico universale (I692) as well as in the map Stato di Ragusi included in this volume. 
The celestial globe was ordered by Federici in pair with the terrestrial globe around I688, since his name appears in the list of the members of the Accademia Cosmografica degli Argonauti founded by Coronelli himself who granted every patron of the globes the membership to the Accademia. The terrestrial globe was produced in Venice and ready in January I689. The celestial globe was also produced in 1692 in Venice and arrived in Fano on a boat from Venice together with the terrestrial globe, after I $693 \cdot{ }^{23}$

Originally, Coronelli intended to have both globes ready by I689. However, he could not finalise the agreement with the engraver Jean-Baptiste Nolin who was supposed to produce the celestial globe in Paris, and he obtained only some drafts of the plates from Nolin's engravings. Coronelli used these drafts to produce the convex celestial globe of the Marciana Library in Venice in I689. The same drafts were also used by the Societas Gallica in France to produce a convex celestial globe in I693. The Federiciana's celestial globe, however, is a concave model produced on new engravings made in Venice in 1692 and released in the market in I693. Several members of the Accademia who had waited for the celestial globe were not satisfied with the Venetian concave model of I692, and Coronelli had to produce another convex celestial globe in I699 (known as Ottoboni globe). One element that was disapproved of in the concave globe realised in I693 was that it was based on the same drawings used for the plates of the convex globe of I 688 but reversed, with the result that all the figures in the globe that are holding some object are left-handed. Moreover, a comparison between the celestial globe of I 692 and the Epitome cosmographica by Coronelli, reveals several discrepancies and mistakes in the naming and numbering of the stars and constellations, although the Epitome was supposed to work as a guide to consult in the production of the globe.

Despite having been considered a partial failure, the concave celestial globe produced in Venice in 1692 is the most widely-spread I Io cm celestial globe by Coronelli. For example, it can be found also in the libraries of Munich, Florence, Ravenna, Jesi among others. However, there are significant differences amongst those samples as several components of these globes are in fact manuscript additions, including the colouring of the globes, the nomenclature of constellations

23. Marica Milanesi, "Il globo celeste di Vincenzo Coronelli nella Biblioteca Federiciana di Fano”, Nuovi Studi Fanesi, I 2 (Fano: Biblioteca Comunale Federiciana, I998): 65-83. 
(in Italian, Latin, French, Greek and Arabic) - thus quintilingual in nature as well, and the dedicatory inscriptions. ${ }^{24}$

Domenico Federici accepted the concave model (Venice, I692), and his globe is distinguished by some specific details. There are three framed inscriptions in the Federiciana's globe. The first, in the northern hemisphere, is the dedicatory inscription from Coronelli to the Republic of Venice. The second, on the southern hemisphere, explains that the celestial globe was meant to represent the sky as it would appear in year I700. The third, by the side of the second framed inscription, explains the perspective of the observer of the globe: the observer looks at the globe as if he was watching the sky from the earth (and not from the Empyrean as it was usually the case for the so called convex globes). The inscription also publicises Coronelli's upcoming publication, "Epitome cosmografica".

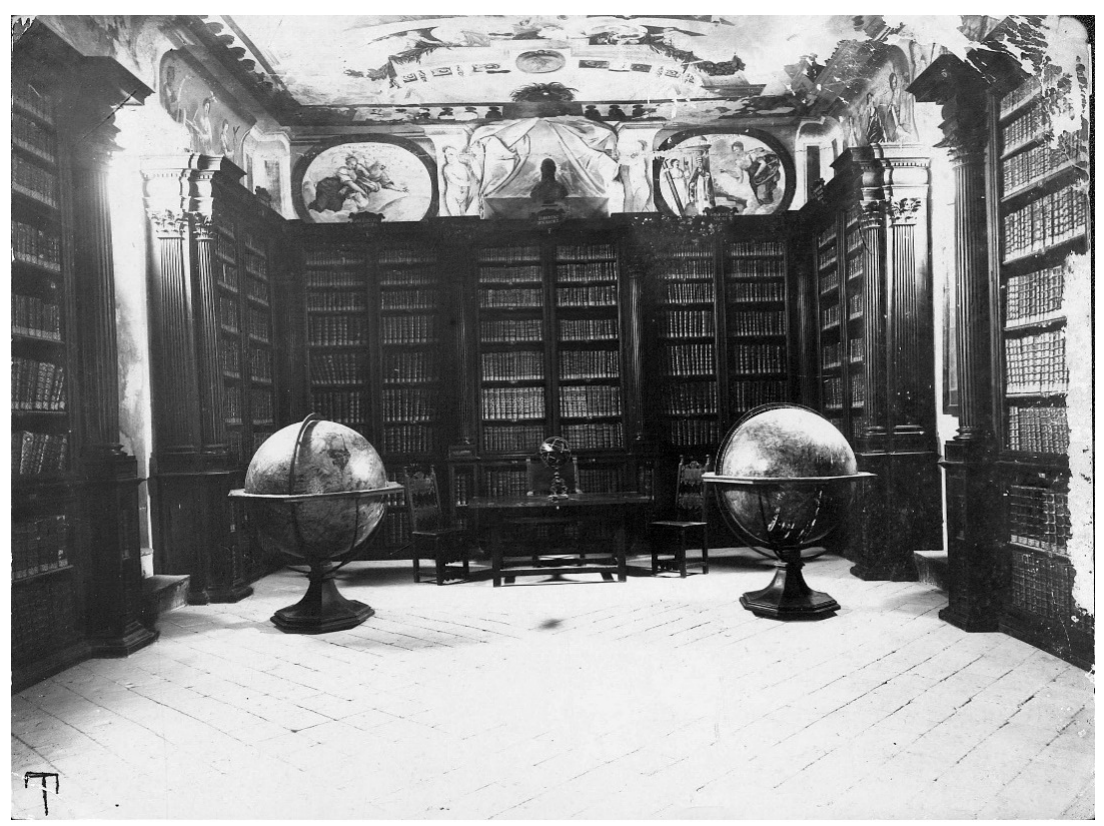

Figure 9. Hall of Globes at the Biblioteca Federiciana (picture taken around I920s, before the earthquakes).

24. There is no comprehensive volume that gathers all the celestial globes still existing by Coronelli so far, but each should be studied as a unique object. 


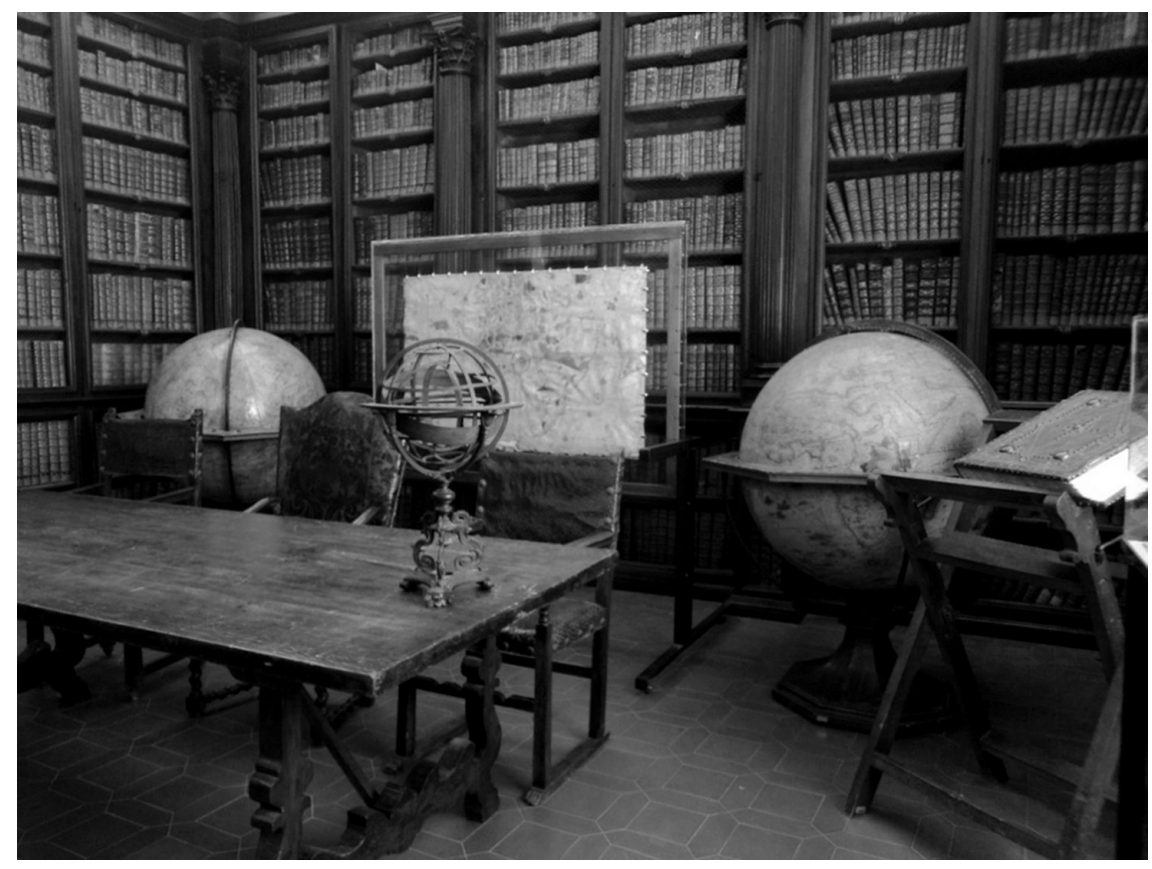

Figure Io. Hall of Globes today.

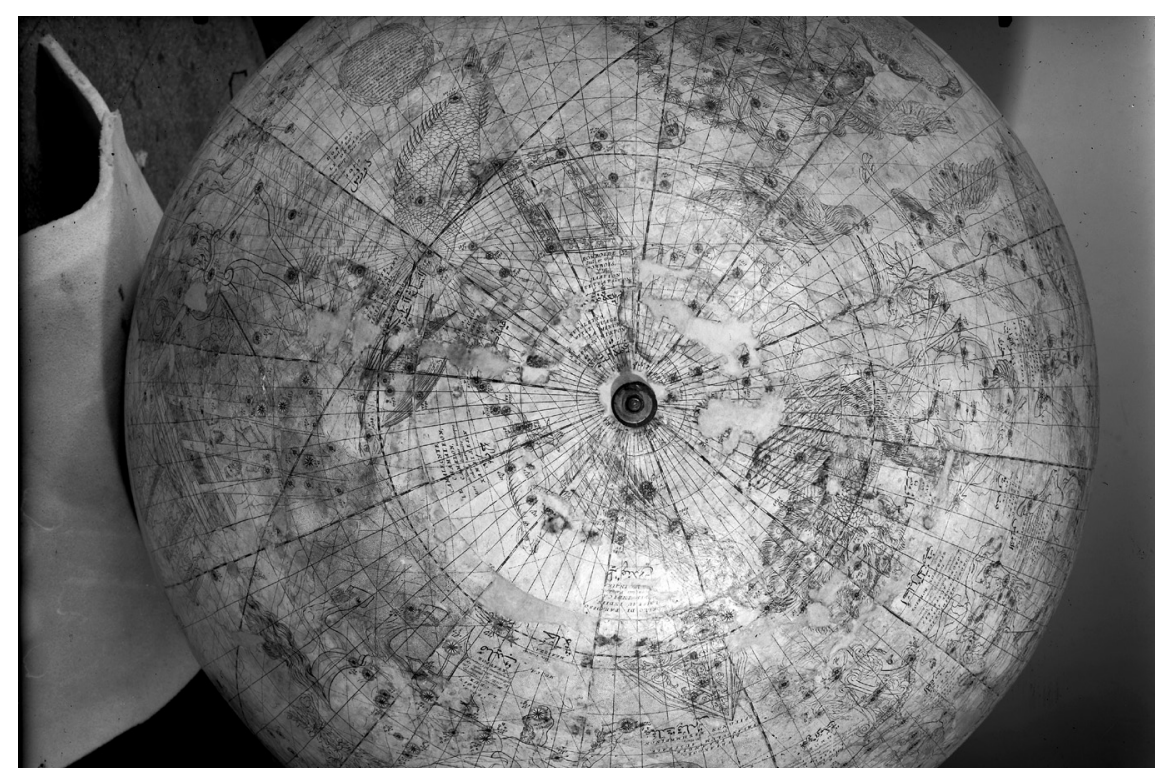

FIGURE I I . Details of the South Pole in the Federiciana's Celestial Globe 


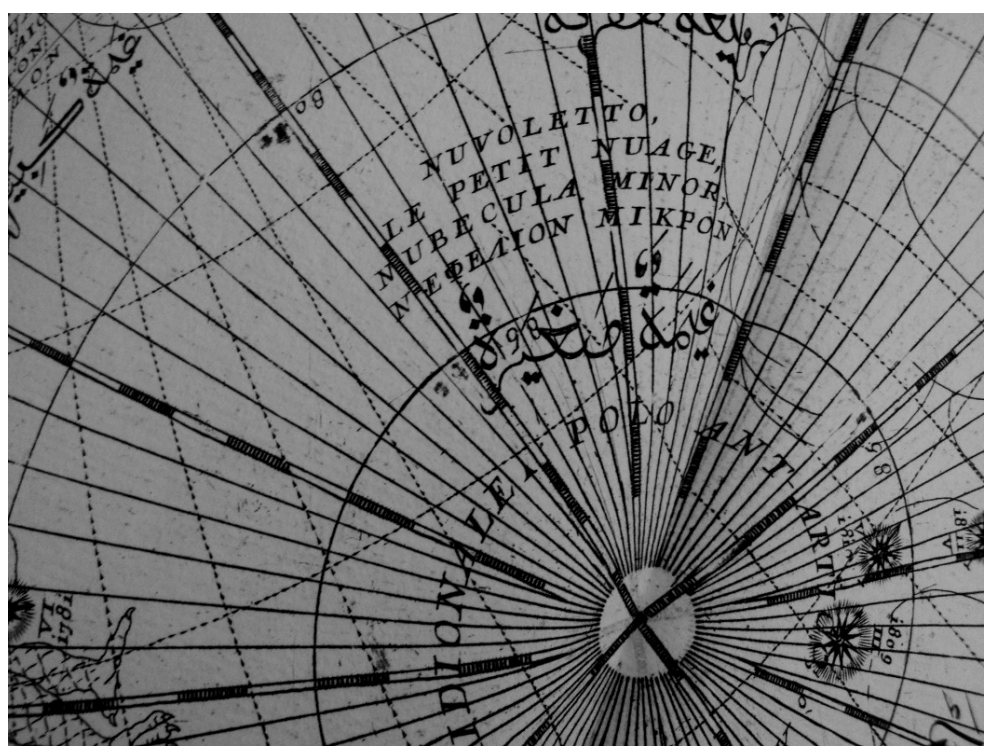

Figure I2. Chart of the South Pole in the Corso geografico universale (I692)

(Biblioteca Federiciana, Shelf mark: 2 M VIII 002 I)

Why did Domenico Federici purchase such an object? What is the context of a celestial globe with Arabic nomenclature in a $\mathrm{I} 7^{\text {th }}$ century library at the periphery of the Papal States?

The town of Fano is less than $50 \mathrm{~km}$ away from Urbino, renowned for the contribution to the Scientific Renaissance in the ${ }^{6} 6^{\text {th }}$ century through the activities of scientists at the Court of the Duke of Urbino, such as Paul of Middelburg ( I 446-I 534), astronomer and pen pal of Nicolaus Copernicus (I473-I 543); Federico Commandino ( I 509-I 575), mathematician and translator of Latin scientific works; Guidobaldo Del Monte ( I 545- I607), astronomer and physician, guarantor of Galileo Galilei; ${ }^{25}$ Bernardino Baldi (I553-I6I7), mathematician and biographer; Muzio Oddi (I569-I639), engineer specialised in the construction of solar clocks; and many others. Urbino was also famous for its workshops specialised in the construction of scientific instruments, such as the Campi workshop for compass, set squares and astrolabes, and the Barocci workshop for scales and

25. Galileo studied Del Monte's Mechanicorum liber ( I 577), and his translation of Archimedes' commentary, In duos Archimedis aequeponderantium libros paraphrasis scholijs illustrata ( I588). Del Monte also helped Galileo to become professor of mathematics in Pisa ( I589) and in Padua ( I 592). 
solar and mechanical clocks. Moreover, the library of the Duke of Urbino held more than 500 titles of scientific works in the fields of mathematics, physics and astronomy, including translations of the works by Muhammad al-Baghdādī (d. I037), Ibn al-Haytham (d. I040), Al-Balkhī (d. 934), Al-Farghān̄̄ (d. 870), AlKindī (d. 866 or 873), and Al-Qabīṣī (d. 967) ${ }^{26}$.

Not far from Urbino, the Biblioteca Federiciana, established in I680 in Fano, holds numerous documents that attest to the conceptual evolution of the sciences, including astronomy, in $\mathrm{I}^{\text {th }}$ century Europe. Already in I64I, Fano saw the institution of the Accademia degli Scomposti (The Academy of the Discomposed) by the Amiani family, whose emblem is a dissembled Keplerian telescope. ${ }^{27}$ The motto of the Academy was "Compositi ad seposita" (United to reach elevated things), meaning that each member of the Academy, specialised in a specific subject, could contribute to the work of each other in order to reach further scientific knowledge. The Biblioteca Federiciana holds the drafts of the project of a telescope dated end $17^{\text {th }}$ beginning $\mathrm{I}^{\text {th }}$ century made by a member of the Accademia. ${ }^{28}$

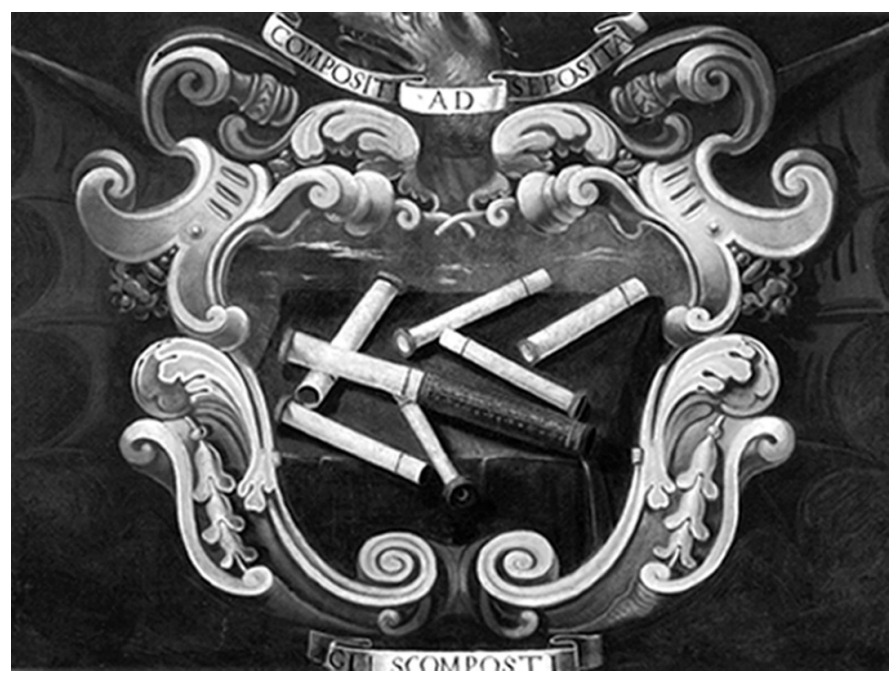

Figure I3, Emblem of the Accademia degli Scomposti in Fano: a disassembled Keplerian telescope

26. M. TAgliabracci (ed.), Scienze (Urbino: Quattroventi, 2015).

27. The telescope has been identified as a Keplerian telescope by specialists of the Museo Galileo in Florence.

28. Biblioteca Federiciana, Shelf mark: Ms. Amiani, n. I26/I. 
Domenico Federici was also a member of the Accademia degli Scomposti and was very interested in astronomy and telescopes. In one of the library catalogues he redacted (Ms. Federici, I I4) there is a section dedicated to books on telescopes. Federici believed that the telescope was the ultimate instrument capable of confirming what is true through the sense of sight over the rational thinking. In a poetic dialogue on an astronomic subject, Federici writes "[I cristalli] sì perfetti che il saggio // tosco fabbricò con l'arte, [...] che tace ogni ragion il senso" (The so perfect crystals [lenses of the telescope] that the wise Tosco [Galileo] skilfully created, [...] so that the sense [of sight through the telescope] defeats reason). ${ }^{29}$ Federici called upon the excellence of the telescope also during an official speech at the Senate of the Republic of Venice, saying: "Si danno, Eccellentissimi Padri, alcune immagini colorite che paiono informi e scontorte, eppure chi le mira nel seno di quel vetro che si chiama cilindro, le conosce diritte e di perfettissima forma [...]" (There are given, my Excellences, my Lords, some distorted and colourful images, but who look at them through the telescope will know that they are straight and of perfect shape). ${ }^{30}$

Federici became a member of the Accademia degli Argonauti, founded by Coronelli in I684, after he purchased the celestial and terrestrial globes. He also acquired several books written by Coronelli and, in general, other volumes on astronomy and other astronomic instruments. Together with Coronelli's globes, the Biblioteca Federiciana holds a $16^{\text {th }}$ century armillary sphere and an astrolabe produced by Bernardino Campi in Urbino in I556. Moreover, archive pictures of the library prior to the earthquake of I920s attest to the existence in the library of two globes by Willem Blaeu (I57I-I638), identified by Edward Luther Stevenson as the terrestrial globe dated I 599 and the celestial globe dated I603..$^{31}$ The archive pictures taken around 1920 also show the original frescoed ceiling of one of the rooms in the Federiciana before its collapse after the earthquake. The ceiling was adorned with a $16^{\text {th }}$ century fresco: the allegoric representation of Veritas holds in her hand a celestial sphere. At the bottom corner on the right, it is possible to identify a man wearing a turban and holding in his hand the miniature of a city.

29. Biblioteca Federiciana di Fano, Shelf mark: Ms. Federici, n. I8.

30. Archivio di Stato di Venezia, Collegio, Esposizione de' Principi, registro 75, cc. 58-6o.

3 I. Edward Luther STEVENSON, Terrestrial and celestial globes: their history and construction including a consideration of their value as aids in the study of geography and astronomy (New Haven: Hispanic Society of America by the Yale university press; London: Humphrey Milford Oxford university press, I92 I): 252. 
Indeed, Federici's library is a manifestation of Federici's interpretation of astronomy as science of the truth (Veritas). The Arabic tradition had a significant role in supporting this representation in terms of both visual and iconic aids, such as the Arabic nomenclature in the globes and the figure in the fresco; and in terms of contents of the library, such as the Arab authors in Latin translation held in the collection and some works in Arabic. ${ }^{32}$ The study of this apparently minor context at the peripheries of more renowned centres of scientific movements not only helps to understand what were the ideas, objects and scientific discoveries that circulated in Europe and beyond in the $\mathrm{I} 7^{\text {th }}$ century, but also highlights the manner in which these ideas, objects and discoveries were perceived, interpreted and represented by the intellectuals of the time.

32. The Biblioteca Federiciana holds also oriental manuscripts, documents and printed books, including: an Ottoman firman from the Court of Mehmed IV dated Io9i Hijrī ( i680), Shelf mark: Ms. Federici, 75/IV; a I $7^{\text {th }}$ century prayer book in Ethiopian, Bevilacqua Collection, Shelf mark: Armadio C; an I $8^{\text {th }}$ century Arabic manuscript with the description of the al-Aqșá Mosque in Jerusalem, Shelf mark: Ms. Fondo Antico, n. Io I; a printed Arabic grammar, Filippo Guadagnoli, Breues Arabicae linguae institutiones (Rome: Tipografia della Congregazione di Propaganda Fide, I642), Shelf mark: 2 M V ooI5; a printed volume on the history of the Arabs, Gregorius Abū AL-FARAJ, Tārīkh mukhtașar al-duwal Historia compendiosa dynastiarum (Oxford: Henry Hall, I663), Shelf mark: I B II ooI5; a printed volume with the description of the Persian pavilion of Chehel Sotun, Petrus Bedik, Cehil Sutun, seu Explicatio utriusque celeberrimi, ac pretiosissimi theatri quadraginta columnarum in Perside orientis, cum adjecta fusiori narratione de religione, moribusq. Persarum, \& eorundem vivendi modo, populis vicinis, alijsq. de hac orientali natione famosissima scitu dignis (Vienna: Leopold Voigt, I678), Shelf mark: I C II 0045; a treatise on the optics by Ibn al-Haytham in Latin, Opticae thesaurus. Alhazeni Arabis libri septem, nunc primùm editi. Eiusdem liber De crepusculis \& nubium ascensionibus. Item Vitellonis Thuringolopoli libri Io. Omnes instaurati, figuris illustrati \& aucti, adiecti etiam in Alhazenum commentarijs, a Federico Risnero (Basel: Episcopius Eusebius \& Episcopius Nikolaus 2. Erben, I 572), Shelf mark: 2 O IX 0020; the treatise on medicine by Ibn Sīnā in Latin, Auicennae Arabum medicorum principis Ex Gerardi Cremonensis uersione, et Andreae Alpagi Bellunensis castigatione. A Ioanne Costce, \& Ioanne Paulo Mongio annotationibus iampridem illustratus. (Venice: Lucantonio Giunta 2., I595), Shelf mark: 2 P x 5-6. The manuscript catalogue (I720 ca.) of Federici's collection mentions other titles that could not be located in the library so far, such as the treatise De Morbis by Costantinus Africanus and a translation of the work by Yuhannā bin Māsawaih. The separate catalogue of the Index Librorum Prohibitorum (List of the prohibited books) that were held at the Federiciana also includes the translation of the Qur'ān in French by André du Ryer (d. I660 or I672) in I647. The copy has not been located in the library yet. 


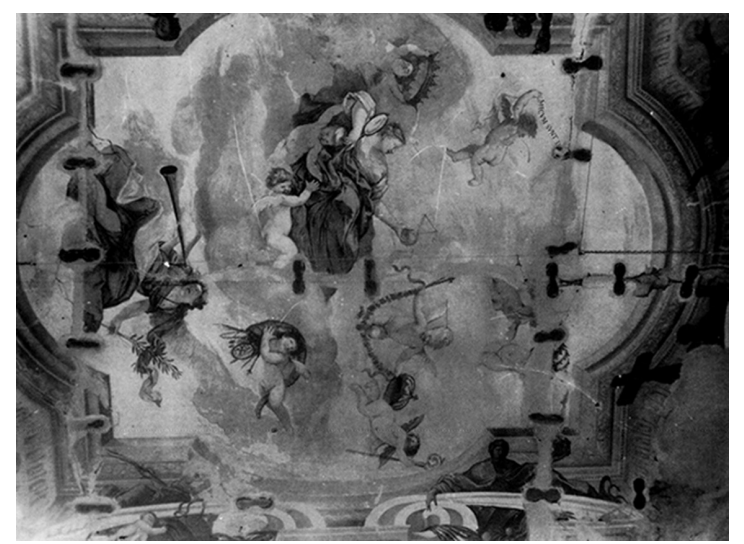

FIGURE I4. The frescoed ceiling of one of the rooms in the Biblioteca Federiciana prior to the earthquake in the I920s.

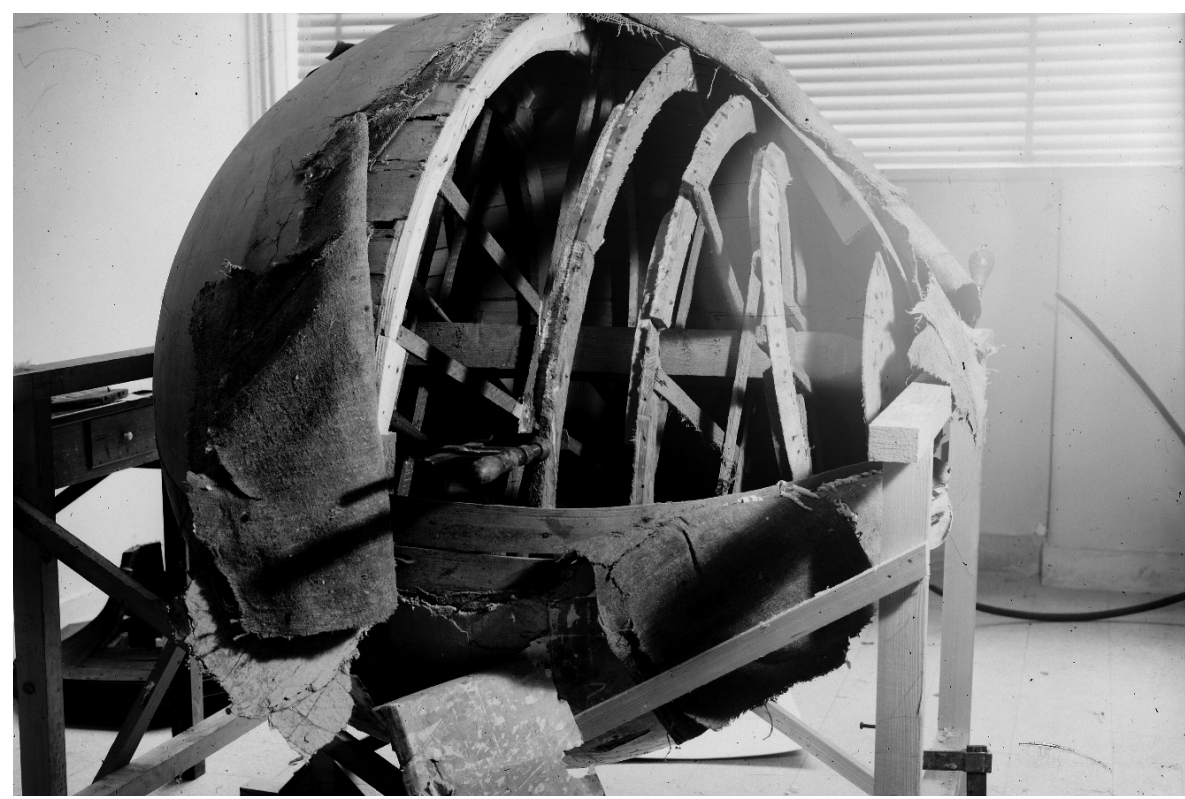

FIGURE I5. The celestial two globes were partially damaged during one of the earthquakes that hit Fano in the I920s. The historical archives MIBAC (Istituto centrale per il restauro e la conservazione del patrimonio archivistico e librario, Rome) recently retrieved the pictures of the globe before and after its restauration in I 964 . 


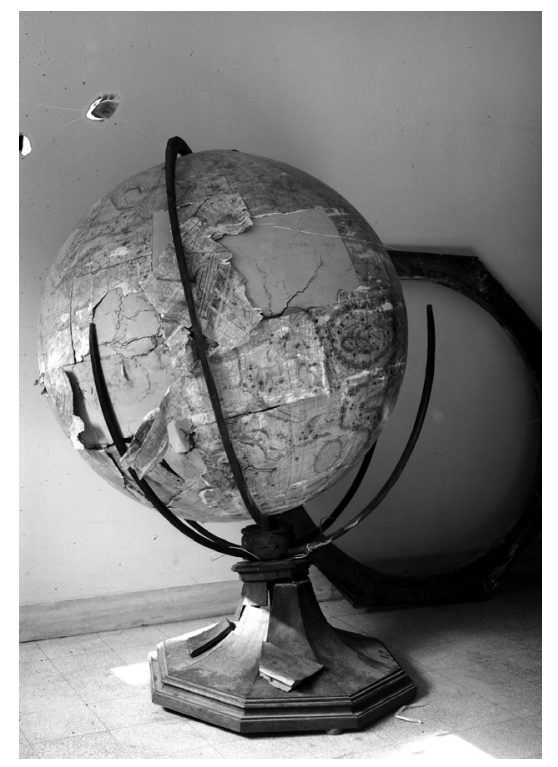

FIGURE I 6. The celestial globe, partially damaged during one of the earthquakes that hit Fano in the I 920 , before its restauration in 1964 .

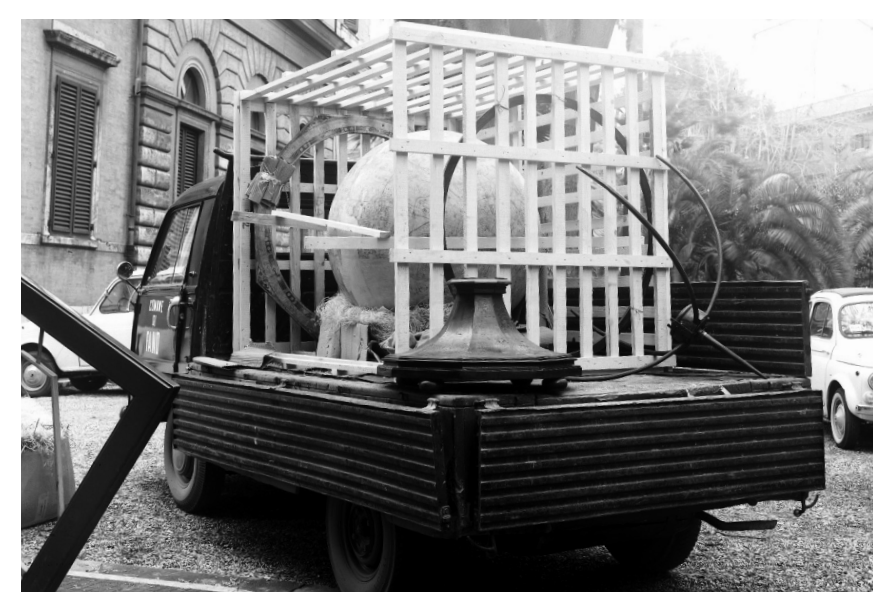

FigURE I7. The celestial globe, partially damaged during one of the earthquakes that hit Fano in the I920s, after its restauration in 1964. 
